\title{
Streptococcus oligofermentans sp. nov., a novel oral isolate from caries-free humans
}

\author{
Huichun Tong, ${ }^{1,2}$ Xuejun $\mathrm{Gao}^{2}$ and Xiuzhu Dong ${ }^{1}$ \\ ${ }^{1}$ State Key Laboratory of Microbial Resources, Institute of Microbiology, Chinese Academy of \\ Sciences, Beijing 100080, P. R. China
${ }^{2}$ Department of Cariology, Endodontology and Operative Dentistry, School of Stomatology, Peking University, Beijing 100081, P. R. China

Xiuzhu Dong

dongxz@sun.im.ac.cn

\begin{abstract}
Five streptococcal strains were isolated from dental plaque and saliva of caries-free humans. The cells were Gram-positive, non-spore-forming, non-motile cocci that were arranged in short chains. The strains were catalase-negative, facultatively anaerobic and produced lactic acid exclusively from glucose fermentation. Biochemical analysis that used both conventional methods and the commercial API 20 Strep system showed that the five strains fermented only a few kinds of sugar. The mean DNA G $+C$ content of the five novel strains was $39 \cdot 5 \pm 0.8 \mathrm{~mol} \%$. Phylogenetic analysis based on 16S rDNA sequence homology indicated that the new isolates represented a novel member of the mitis group of the genus Streptococcus, related most closely to the recently described species Streptococcus sinensis. DNA-DNA relatedness between novel strain LMG $21535^{\top}$ and type strains of phylogenetically related species of oral streptococci was 7·1-16.4\%. Therefore a novel Streptococcus species, Streptococcus oligofermentans sp. nov.,

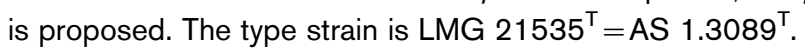

Oral streptococci comprise part of the normal microbial flora of the oral cavity and upper respiratory tract of humans (Hardie \& Marsh, 1978). However, they are also involved (usually as opportunistic pathogens) in a number of human diseases, such as dental caries (Fitzgerald et al., 1960; Krasse, 1966) and bacterial endocarditis (Dyson et al., 1999). On the basis of 16S rDNA homology, oral streptococci have been classified into five phylogenetic groups (Kawamura et al., 1995). Among them, the mitis group has been considered to be difficult to identify by biochemical methods because of the lack of reliable traits (Ezaki et al., 1988), so genetic characterizations are necessary. Recently, four new streptococcal species that belong to the mitis group have been proposed, based mainly on genetic and phylogenetic analyses (Kawamura et al., 1998; Willcox et al., 2001; Woo et al., 2002).

During a survey of oral acid-producing bacteria of nasopharyngeal carcinoma patients, we isolated five strains of oral streptococci from dental plaques and saliva. Compared with described oral streptococcal species, these strains fermented only a few kinds of sugars. Phylogenetic analysis

Published online ahead of print on 20 December 2002 as DOI 10.1099/ijs.0.02493-0.

The GenBank/EMBL/DDBJ accession number for the 16S rDNA sequence of Streptococcus oligofermentans LMG $21535^{\top}$ is AY099095.

Tables showing the biochemical characteristics of Streptococcus oligofermentans and levels of DNA-DNA relatedness with closely related species are available as supplementary data in IJSEM Online. based on 16S rDNA sequence homology and DNA-DNA relatedness indicated that the new isolates were closely related to the mitis group, but were a distinctive member of this group.

Streptococcus sanguinis ATCC $10556^{\mathrm{T}}$ and Streptococcus mitis NCTC $12261^{\mathrm{T}}$ were purchased from the China Microbiological Culture Collection Center (CMCC) and Streptococcus sinensis HKU4 ${ }^{\mathrm{T}}$ and Streptococcus gordonii ATCC $10558^{\mathrm{T}}$ were kindly provided by Professor P. Woo of the University of Hong Kong and the China General Microbiological Culture Collection Center (CGMCC), respectively. In our laboratory, novel strains were isolated and purified on brain-heart infusion (BHI; Oxoid) agar plates supplemented with $5 \%$ defibrinated sheep blood, and cultivated at $37^{\circ} \mathrm{C}$ under an atmosphere of $\mathrm{N}_{2} / \mathrm{CO}_{2}(95 / 5 \%)$. End products of glucose fermentation in tryptone/peptone/yeast extract/ glucose (TPYG) medium (Scardovi, 1986) were detected by GC (GC-14B; Shimadzu). Biochemical traits were determined by using both conventional methods (Hardie, 1986) and the API 20 Strep system (bioMérieux). All tests were performed in duplicate.

Genomic DNA was extracted and purified by using a previously described modification of the method of Marmur (1961) (Dong et al., 2000). DNA G + C content was determined by thermal denaturation (Marmur \& Doty, 1962). DNA-DNA relatedness was determined at $66 \cdot 3{ }^{\circ} \mathrm{C}$ on the basis of the DNA-DNA liquid reassociation rate (De Ley et al., 1970) by using a 752 spectrophotometer (Shanghai 
Third Analytical Company, China) with a thermal controller. 16S rDNA was amplified by PCR with genomic DNA as the template and sequenced with an ABI PRISM 377XL DNA sequencer (Applied Biosystems). The most closely related sequences were retrieved from GenBank and aligned with those of the novel strains; similarity analysis was performed by using the DNAMAN program (version 4.0; Lynnon Biosoft). A phylogenetic tree was constructed using the neighbour-joining method (Saitou \& Nei, 1987), implemented in the DNAMAN program. The stability of the clustering of the tree was evaluated by bootstrap analysis of 1000 datasets.

The novel strains produced lactic acid as the exclusive endproduct of glucose fermentation. Their mean generation time was $2 \cdot 17 \pm 0 \cdot 26 \mathrm{~h}$. The five strains utilized only a few sugars, such as sucrose, glucose, mannose and maltose; detailed data are available in IJSEM Online. Furthermore, they were different from most other oral streptococci in some biochemical characteristics (Table 1), such as not utilizing lactose or hydrolysing arginine; however, hippurate is hydrolysed.

The complete 16S rDNA sequence of novel strain LMG $21535^{\mathrm{T}}$ was compared with those of the type strains of 19 related oral streptococcal species and Bacillus subtilis NCFB $1769^{\mathrm{T}}$. On the basis of $16 \mathrm{~S}$ rDNA sequence similarity in a 1332 bp consensus fragment, a phylogenetic tree rooted with B. subtilis was constructed (Fig. 1). Strain LMG $21535^{\mathrm{T}}$ clustered in the mitis group with highest similarity to
S. sinensis $\mathrm{HKU}^{\mathrm{T}}(97 \cdot 7 \%)$, a recently described oral streptococcus (Woo et al., 2002a, b). Similarity levels between strain LMG $21535^{\mathrm{T}}$ and other members of the mitis group ranged from $94 \cdot 2$ to $95 \cdot 8 \%$, suggesting that this strain could represent a novel member of the mitis group, closely related to $S$. sinensis.

As strain LMG $21535^{\mathrm{T}}$ was phylogenetically related to the streptococci in the mitis group, DNA-DNA relatedness between them was analysed. DNA-DNA reassociation rates were $72-100 \%$ among the five novel strains, indicating that they were a homogeneous genetic group. However, DNA-DNA relatedness between strain LMG $21535^{\mathrm{T}}$ and four streptococcal species in the mitis group was only $7 \cdot 1-16 \cdot 4 \%$, much lower than the DNA homology threshold for a species $(70 \%)$. Values of DNA-DNA relatedness between strain LMG $21535^{\mathrm{T}}$ and closely related species in the mitis group are available as supplementary data in IJSEM Online. The mean DNA G $+\mathrm{C}$ content of the five novel strains was $39 \cdot 46 \pm 0.79 \mathrm{~mol} \%(39 \cdot 89 \mathrm{~mol} \%$ for the type strain, LMG $21535^{\mathrm{T}}$ ).

Although our strains exhibited high 16S rDNA similarity with S. sinensis $(97 \cdot 7 \%)$, DNA-DNA relatedness between them was only $15 \%$. The difference in biochemical characteristics was also obvious (Table 1). By combining phenotypic, genotypic and phylogenetic characteristics, it is evident that the novel strains belong to a different species from S. sinensis and other oral streptococci, for which the name Streptococcus oligofermentans sp. nov. is proposed.

Table 1. Biochemical characteristics that differentiate $S$. oligofermentans sp. nov. from related Streptococcus species in the mitis group

Species: 1, S. oligofermentans; 2, S. sinensis; 3, S. sanguinis; 4, S. gordonii; 5, S. mitis; 6, Streptococcus peroris; 7, Streptococcus infantis; 8, Streptococcus australis; 9, Streptococcus oralis; 10, Streptococcus parasanguinis; 11, Streptococcus pneumoniae; 12, Streptococcus cristatus.,$+>90 \%$ of strains positive;,$-<10 \%$ of strains positive; D,$+ 50-89 \%$ of strains positive; $\mathrm{D}-, 11-49 \%$ of strains positive; NT, not tested.

\begin{tabular}{|c|c|c|c|c|c|c|c|c|c|c|c|c|}
\hline Character & 1 & $2^{\star}$ & $3 \dagger$ & $4 \dagger$ & $5 \dagger$ & $6 \dagger$ & $7 \dagger$ & $8 \ddagger$ & $9 \dagger$ & $10 \dagger$ & $11 \dagger$ & $12 \dagger$ \\
\hline \multicolumn{13}{|l|}{ Hydrolysis of: } \\
\hline Arginine & - & + & + & + & - & - & - & + & - & + & $\mathrm{D}-$ & + \\
\hline Hippurate & + & - & - & - & - & - & - & - & - & - & - & NT \\
\hline \multicolumn{13}{|l|}{ Acid produced from: } \\
\hline Lactose & $\mathrm{D}-$ & + & + & + & + & + & + & + & + & + & + & + \\
\hline Raffinose & $\mathrm{D}-$ & - & $\mathrm{D}+$ & - & $\mathrm{D}-$ & - & - & - & $\mathrm{D}+$ & $\mathrm{D}+$ & + & $\mathrm{D}-$ \\
\hline Trehalose & $\mathrm{D}-$ & + & + & + & - & - & - & - & $\mathrm{D}-$ & $\mathrm{D}-$ & + & $\mathrm{D}+$ \\
\hline Melibiose & - & - & $\mathrm{D}+$ & - & $\mathrm{D}-$ & - & - & - & $\mathrm{D}+$ & $\mathrm{D}+$ & - & $\mathrm{D}-$ \\
\hline \multicolumn{13}{|l|}{ Production of: } \\
\hline$\alpha$-Galactosidase & $\mathrm{D}-$ & - & $\mathrm{D}-$ & + & $\mathrm{D}+$ & - & - & - & $\mathrm{D}+$ & $\mathrm{D}+$ & + & $\mathrm{D}-$ \\
\hline$\beta$-Galactosidase & - & - & + & + & $\mathrm{D}+$ & - & + & - & $\mathrm{D}^{-}$ & $\mathrm{D}^{-}$ & - & $\mathrm{D}^{-}$ \\
\hline Alkaline phosphatase & $\mathrm{D}-$ & - & $\mathrm{D}-$ & + & $\mathrm{D}+$ & + & - & + & $\mathrm{D}+$ & $\mathrm{D}+$ & - & - \\
\hline
\end{tabular}

${ }^{*}$ Data from Woo et al. (2002a).

$\dagger$ Data from Kawamura et al. (1998).

$\ddagger$ Data from Willcox et al. (2001). 




Fig. 1. Dendrogram based on $16 \mathrm{~S}$ rDNA sequence homology in a consensus $1332 \mathrm{bp}$ fragment, indicating the phylogenetic relationships of $S$. oligofermentans LMG $21535^{\top}$ and 19 other Streptococcus species. The tree was rooted with $B$. subtilis NCFB $1769^{\top}$ and constructed by using the neighbour-joining method with bootstrap values calculated from 1000 trees. Numbers at branch points represent bootstrap support (\%); GenBank accession numbers of $16 \mathrm{~S}$ rDNA sequences are given in parentheses. Bar, $1 \%$ sequence divergence.

\section{Description of Streptococcus oligofermentans sp. nov.}

Streptococcus oligofermentans (o.li.go.fer.men'tans. Gr. adj. oligos little, scanty; L. part. adj. fermentans fermenting; N.L. part. adj. oligofermentans fermenting few compounds).

Gram-positive, non-motile, non-spore-forming cocci, arranged in short chains, about $0 \cdot 7 \mu \mathrm{m}$ in diameter after $24 \mathrm{~h}$ growth in $\mathrm{BHI}$ medium at $37^{\circ} \mathrm{C}$. Catalase-negative. Colonies on BHI blood agar are even, locally rough, dark yellow with $\alpha$-haemolysis and approximately $0 \cdot 5-1 \cdot 0 \mathrm{~mm}$ in diameter after $24 \mathrm{~h}$ cultivation. Facultatively anaerobic. Optimum temperature for growth is $37^{\circ} \mathrm{C}$; temperature range for growth is $25-41^{\circ} \mathrm{C}$. Optimum $\mathrm{pH}$ is $7 \cdot 0 ; \mathrm{pH}$ range for growth is $5 \cdot 30-8 \cdot 95$. Sucrose, D-glucose, mannose and maltose are fermented; mannitol, salicin, sorbitol, arabinose, inulin, melibiose, cellobiose, arbutin, amygdalin, ribose, starch and glycogen are not fermented. Fermentation of lactose, trehalose and raffinose is variable. Hippurate is hydrolysed. Arginine and aesculin are not hydrolysed. Voges-Proskauer test is negative. DNA G $+\mathrm{C}$ content is $39 \cdot 46 \pm 0.79 \mathrm{~mol} \%$ (39.89 mol\% for the type strain).
The type strain is deposited in both the China General Microbiological Culture Collection Center (CGMCC; Beijing) and in BGGM/LMG (Gent, Belgium) under accession numbers AS $1.3089^{\mathrm{T}}$ and LMG $21535^{\mathrm{T}}$, respectively. Strains were isolated from the dental plaque and saliva of humans.

\section{Acknowledgements}

This study was supported by the grants of the ' 863 ' program from the Chinese Ministry of Sciences and Technology and the Chinese Academy of Sciences.

\section{References}

De Ley, J., Cattoir, H. \& Reynaerts, A. (1970). The quantitative measurement of DNA hybridization from renaturation rates. Eur J Biochem 12, 133-142.

Dong, X., Xin, Y., Jian, W., Liu, X. \& Ling, D. (2000). Bifidobacterium thermacidophilum sp. nov., isolated from an anaerobic digester. Int J Syst Evol Microbiol 50, 119-125.

Dyson, C., Barnes, R. A. \& Harrison, G. A. (1999). Infective endocarditis: an epidemiological review of 128 episodes. J Infect 38, 87-93.

Ezaki, T., Hashimoto, Y., Takeuchi, N., Yamamoto, H., Liu, S. L., Miura, H., Matsui, K. \& Yabuuchi, E. (1988). Simple genetic method to identify viridans group streptococci by colorimetric dot hybridization and fluorometric hybridization in microdilution wells. J Clin Microbiol 26, 1708-1713.

Fitzgerald, R. J., Jordan, H. V. \& Stanley, H. R. (1960). Experimental caries and gingival pathologic changes in the gnotobiotic rat. $J$ Dent Res 39, 923-935.

Hardie, J. M. (1986). Oral streptococci. In Bergey's Manual of Systematic Bacteriology, vol. 2, pp. 1054-1063. Edited by P. H. A. Sneath, N. S. Mair, M. E. Sharpe \& J. G. Holt. Baltimore: Williams \& Wilkins.

Hardie, J. M. \& Marsh, P. D. (1978). Streptococci and the human oral flora. In Streptococci, pp. 157-206. Edited by F. A. Skinner \& L. B. Quesnel. London: Academic Press.

Kawamura, Y., Hou, X.-G., Sultana, F., Miura, H. \& Ezaki, T. (1995). Determination of $16 \mathrm{~S}$ rRNA sequences of Streptococcus mitis and Streptococcus gordonii and phylogenetic relationships among members of the genus Streptococcus. Int J Syst Bacteriol 45, 406-408.

Kawamura, Y., Hou, X.-G., Todome, Y., Sultana, F., Hirose, K., Shu, S.-E., Ezaki, T. \& Ohkuni, H. (1998). Streptococcus peroris sp. nov. and Streptococcus infantis sp. nov., new members of the Streptococcus mitis group, isolated from human clinical specimens. Int J Syst Bacteriol 48, 921-927.

Krasse, B. (1966). Human streptococci and experimental caries in hamsters. Arch Oral Biol 11, 429-436.

Marmur, J. (1961). A procedure for the isolation of deoxyribonucleic acid from microorganisms. J Mol Biol 3, 208-218.

Marmur, J. \& Doty, P. (1962). Determination of the base composition of deoxyribonucleic acid from its thermal denaturation temperature. J Mol Biol 5, 109-118.

Saitou, N. \& Nei, M. (1987). The neighbor-joining method: a new method for reconstructing phylogenetic trees. Mol Biol Evol 4, 406-425.

Scardovi, V. (1986). Genus Bifidobacterium Orla-Jensen $1924472^{\mathrm{AL}}$. In Bergey's Manual of Systematic Bacteriology, vol. 2, pp. 1418-1434. 
Edited by P. H. A. Sneath, N. S. Mair, M. E. Sharpe \& J. G. Holt. Baltimore: Williams \& Wilkins.

Willcox, M. D. P., Zhu, H. \& Knox, K. W. (2001). Streptococcus australis sp. nov., a novel oral streptococcus. Int J Syst Evol Microbiol 51, 1277-1281.

Woo, P. C. Y., Tam, D. M. W., Leung, K.-W., Lau, S. K. P., Teng, J. L. L., Wong, M. K. M. \& Yuen, K.-Y. (2002a). Streptococcus sinensis sp. nov., a novel species isolated from a patient with infective endocarditis. $J$ Clin Microbiol 40, 805-810.

Woo, P. C. Y., Tam, D. M. W., Leung, K.-W., Lau, S. K. P., Teng, J. L. L., Wong, M. K. M. \& Yuen, K.-Y. (2002b). Streptococcus sinensis sp. nov. In Validation of the Publication of New Names and New Combinations Previously Effectively Published Outside the IJSEM, List no. 87. Int J Syst Evol Microbiol 52, 1437-1438. 